\title{
Strategy or disaster: New-style river regulation as an issue of national security
}

\author{
FERENC SCHWEITZER ${ }^{1}$
}

\begin{abstract}
Protection against floods along the Tisza, Danube and their major tributaries have become an issue of state security significance since nearly 2.5 million lives are affected. The floods of 1999 and 2000 on the Tisza and the 2013 flood on the Danube demonstrated that the 150-year-old system was corrected at the expense of outstanding financial investment and human effort although it is clear that the flood-protection structures built observing contemporary prescriptions are not able to provide the necessary protection. With the rising flood levels and other reasons (including climate change, tectonic movements, changes in river mechanism and others), their protection potential will be further reduced in the future. The warning signs are getting more and more frequent. Since 1864 there have been almost 30 disastrous floods on the Tisza alone. Over the past quarter of a century there happened ten high floods, during which the flood-control system could not ensure the safe conveyance of flood waves. The changes on the Danube were also very remarkable in spite of the major water engineering interventions along the Hungarian section of the river.
\end{abstract}

Keywords: river regulation, national security, floods, Tisza, Danube

\section{Introduction}

About one-fourth of the territory of Hungary is floodplain area, protected by 4,220 $\mathrm{km}$ of flood-control dykes. The streams are divided between the systems of two major rivers, the Tisza and the Danube. In the areas endangered by floods 2.5 million people live on almost 700 settlements. This geomorphological surface accommodates almost $32 \%$ of railways, $15 \%$ of public roads and more than 2,000 industrial plants. Such structures are located encircled by 19,000 to $20,000 \mathrm{~km}^{2}$ of valuable agricultural land. The large-scale flood regulation works following the formation of the Tisza Valley Flood Regulation Association in 1846, primarily the construction of dykes along the Danube, the Tisza and their major tributaries, changes of the alignment of main channels, the creation of side-branches and main defence lines confining floodways, the establishment of artificial channel sections, the cut-off of bends, the drainage of swamps, the improvement of navigation conditions, the prevention of ice-jam and ice-free floods and investments observing water management and land utilization aspects were the most comprehensive activity of nature transformation in Europe of that time and also the largest-scale regional development programme in Hungary to date.

After 150 years it became clear that the concept was not correct in all aspects due to political and economic decision making, for instance, setting navigation goals allowing too narrow active floodplains, draining swamps on the lower floodplain levels, prioritizing the interests of large-scale agricultural cultivation, deficient design and implementation of main canals (IHRIG, D. 1952). We are aware that since then the stability of embankments has been reduced, the transport capacity of large rivers has increased after regulation, current velocities have increased, low-water

\footnotetext{
${ }^{1}$ DSc, research professor emeritus. Geographical Institute, Research Centre for Astronomy and Earth Sciences HAS, H-1112 Budapest, Budaörsi út 43. E-mail: schweitzer.ferenc@csfk.mta.hu
} 
beds have incised deeply and deeper channels have led to the sinking of the groundwater table, which - according to PÁLfaI, I. (2004) - increased susceptibility to drought. We also know that the narrowing of the low floodplain level within dykes results in rapid sedimentation on the active floodplain, the surface of which rises and, thus, the levels and durations of floods of equal height are increased.

The Trianon Peace Treaty dissected the unified flood-control system of historical Hungary. As a consequence, Hungary became defenceless as far as water management is concerned and exposed to floods. River regimes in the catchments encircled by the Eastern Alps and the Carpathians could not be influenced.

Before 1976 the primary measure of flood security was the difference between the highest flood level observed to date and the height of embankment crown. Since 1976 this value is only registered for some river sections. The desirable difference was raised from $70 \mathrm{~cm}$ in 1852 to $100-150 \mathrm{~cm}$ in 1934, when the dimensions of the minimum dyke crosssections were also specified. The average difference for the Tisza River was 100-120 m in 1956 and its minimum was above $70 \mathrm{~cm}$ along the whole length of the river. Today the average is below $40 \mathrm{~cm}$ and over more than a hundred kilometres long section it is below $20 \mathrm{~cm}$. As a consequence, during the 2000 flood a temporary dyke had to be built along a 155-km-long section of the Middle Tisza and the existing dykes had to be raised (Schweitzer, F. and Nagy, I. 2011).

Since 1960 the afforestation of active floodplains began, summer dykes and resorts appeared, arable and grazing lands were abandoned and invasive plants (like false indigo, Amorpha fruticosa) started to spread. All these contributed to the rapid rise of flood levels and increased floodplain sedimentation.

\section{Discussion}

The water management investments in dyke construction have a lasting impact, for decades or even centuries. Replacements are slow and costly to accomplish. For instance, the active floodplain of the Körös Rivers was designed to have only 50-70 m width in the late 19th century. Beyond the Hungarian-Romanian border, however, floodplain width is $150-200 \mathrm{~m}$. Therefore, water is funnelled into the narrow sections, flood waves pile up and result in dam breaching, boil activity and excess water inundations. To mitigate this hazard the active floodplain in Hungary should be broadened through the backward placement of flood-control dykes (SCHWEITZER, F. 2001).

Engineering interventions are not able to fully eliminate problems. Regional development and landscape rehabilitation are outstanding tasks. In order to prevent disasters political decisions are indispensable. It is to be noted that in dry periods the awareness of flood risk is greatly reduced in the general public and among most of the political leaders. However, when floods occur again, like in November 1998, when 17 dry years were followed by flood and led to catastrophic situation on the Upper Tisza, opinions and attitudes have to be rethought, even by those who refute the existence of flood hazard.

On the catchments of rivers in Hungary - with special regard to natural and economic processes in the active floodplains - flood levels can rise significantly. The reduction of flood conductivity of the floodway amounted to $3 \mathrm{~cm}$ per year for the period 1970-2010 (SCHWEITZER, F. and NAGY, I. 2011).

In the drainage basin of the Tisza River, e.g. on the upper section in the Carpathian foreland, there were 19 destructive floods after 1947 (VÁGÁs, I. 1982, 1984). Researchers see the cause of this in unmerciful deforestation, mining activities and, as a consequence, common landslides and soil erosion inducing enhanced sediment transport. Although the significance of deforestation is debated by some, I. SzIKURA (personal communication, 2001), a professor of botanic at the Uzhgorod National University emphasizes that the forest foliage intercepts up to half of rainfall, reduces snowmelt to half and increases the amount of infiltration and storage of water in the soil. The fact is also important to note that in the North-Eastern Carpathians the upper timber line has moved 200-300 m lower. 
The sediment transport capacity of rivers in the Carpathian Basin has ever been large. Even the settlement on the isolated higher floodplain levels rising above the low floodplain level were occasionally inundated by floods because on the low levels around them silts accumulated. Along the present-day Tisza River, the divide surface of NE to SW alignment, built up of loess and loess-like deposits, was dissected by high flood discharges, e.g. at the breach of the Mirhó Stream. These locations could have been sites of channel changes of the Tisza during floods. Between them the paleochannels of the Tisza can be detected (Figure 1) showing huge meanders filled continuously with excess water (Figure 2).

Very rapid urbanization in the drainage basin further enhanced the natural rate of sediment transport over the 150 years of flood defence and sedimentation accelerated on certain sections, manifested in the accu- mulation of point-bars and natural levees. The consequence was that the heights of the dykes had to be raised time after time, since 1850 on 5-6 occasions (Figures 3 and 4).

If nothing changes, they have to be raised further (Schweitzer, F. 2001). In the active floodplain of the Tisza River the accumulation of sediment has reached 200-240 cm south of Szolnok and $400 \mathrm{~cm}$ on the Vajdaság (Vojvodina) section in Serbia, while along the Körös rivers accumulation amounted to $140-160 \mathrm{~cm}$. The rapid growth in the rate of sedimentation in the active floodplain is indicated by the distribution of ${ }^{137} \mathrm{Cs}$ in the cross-section at Szolnok (Braun, M. et al. 2001) (Photo 1). Since the Chernobil nuclear accident (1986) sedimentation estimated from the concentration of ${ }^{137} \mathrm{Cs}$ activity is $30-35 \mathrm{~cm}$ until 2000. In author's opinion this rapid sedimentation affects the water levels of lakes in Hungary, including Lake Balaton.

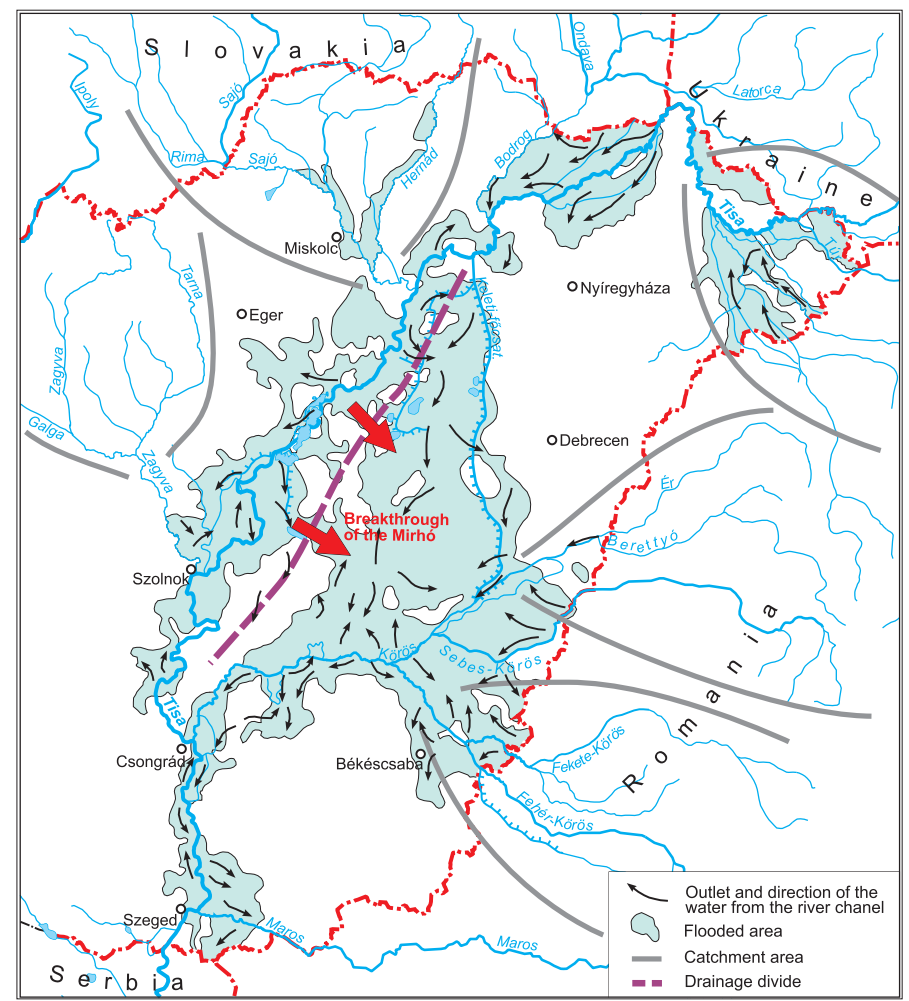

Fig. 1. Waterlogged areas in the Tisza valley prior to water regulation (edited by SchwEITZER, F. 2000) 


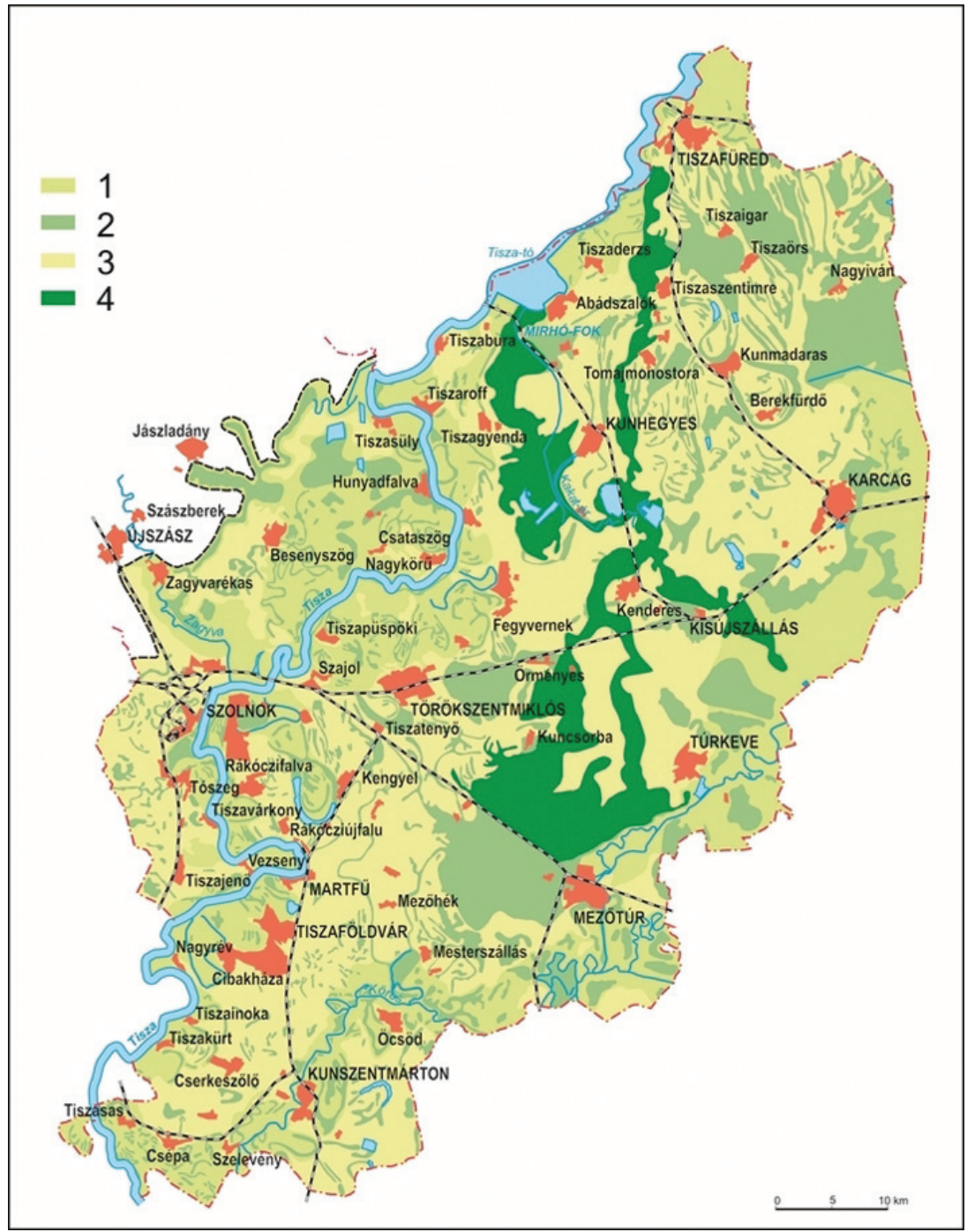

Fig 2. Relationship between floods and inundation hazard on the engineering geomorphological map of the Mirhó-fok. (eds: Schweitzer, F. and BALOGH, J. 2001). - 1 = low floodplain; 2 = areas with inundation hazard; 3 = high floodplain; 4 = areas suitable for water retention

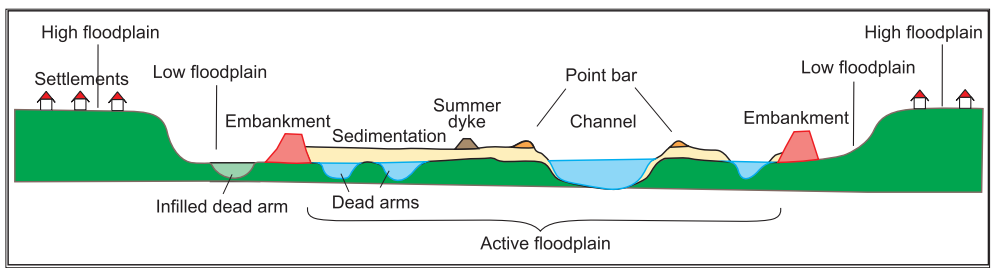

Fig. 3. Rising of the flood control embankments since river regulation (after ScHweItzer, F. 2001) 


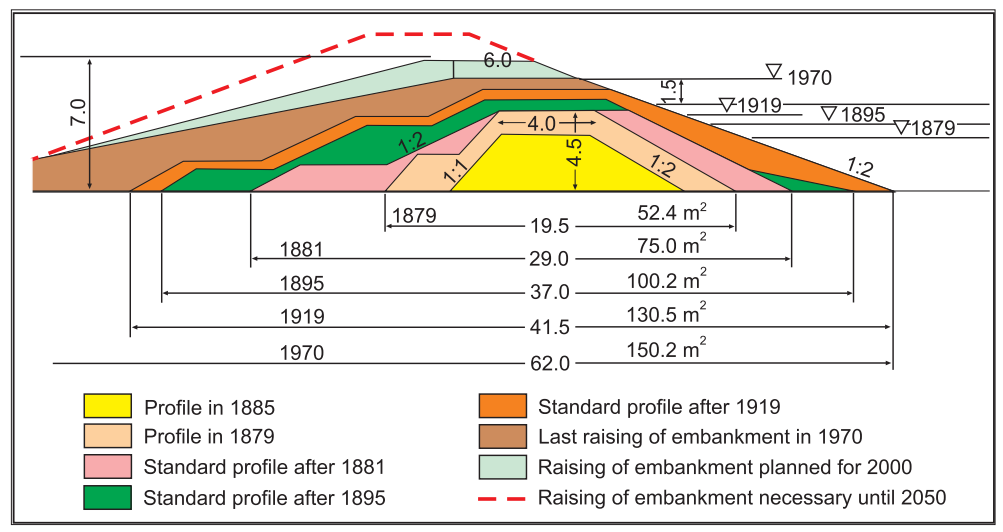

Fig. 4. Rise of the embankments (edited by SchweItzer, F. after VáGÁs, I. 1982)

In the active floodplains of rivers huge amounts of sediment arriving from the catchments are deposited. Evidenced by the history of dykes along the Tisza (raised on 6-7 occasions), the further heightening of floodcontrol embankments is no long-term solution (SChWEITZER, F. 2009).

The floodways are less and less suitable to conduct floods of both the Danube and the Tisza. In 2000, when the largest ever flood passed down on the Tisza, the flood discharge was only slightly higher than in 1970.
Maximum flood level, however, was at 1,041 $\mathrm{cm}$ at Szolnok, $1.5 \mathrm{~m}$ higher than before. The only explanation lies in the deterioration of flood conductivity caused by sedimentation in the active floodplain (Table 1).

Unfortunately, this process has been neglected in flood hazard research. Disregarding sedimentation, dyke heights had to be raised in every 20-25 years over the last 150 years (Schweitzer, F. 2000; NAGY, I. et al. 2001). If this deterioration continues, the high flood waves of the last decades will return within

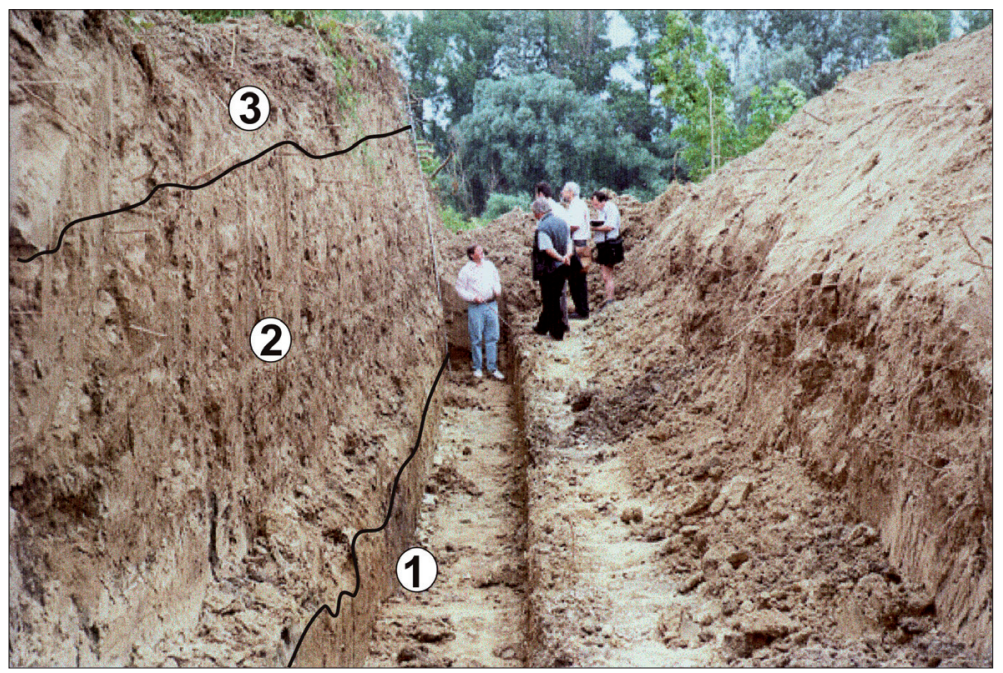

Photo 1. Section South from Szolnok with intense floodplain sedimentation. $-1=$ alluvial meadow soil formed prior to flood control; $2=200-230 \mathrm{~cm}$ thick siltation; 3 $=30-40 \mathrm{~cm}$ thick sediments deposited between 1986 and 2000. (Photo by Schweitzer, F. 2001) 
Table 1. Maximum flood levels at river gauges of the Middle Tisza region in 1999 and 2000

\begin{tabular}{l|c|c|c|c|c}
\hline \multicolumn{1}{c|}{ Gauge } & $\begin{array}{c}1999 \text { maximum } \\
\text { in cm }\end{array}$ & $\begin{array}{c}1999 \text { maximum } \\
\text { related to design } \\
\text { flood level, cm }\end{array}$ & $\begin{array}{c}2000 \text { maximum, } \\
\mathrm{cm}\end{array}$ & $\begin{array}{c}\text { 1999 maximum } \\
\text { related to design } \\
\text { flood level, cm }\end{array}$ & $\begin{array}{c}\text { Growth of maxi- } \\
\text { mum flood levels } \\
\text { compared to pre- } \\
\text { 1999 period, cm }\end{array}$ \\
\hline Tiszafüred & 835 & +21 & 881 & +67 & 93 \\
Kisköre & 978 & +47 & 1,030 & +99 & 122 \\
Tiszaroff & 1,033 & +39 & 1,088 & +94 & 130 \\
Tiszabö & 1,023 & +19 & 1,080 & +76 & 131 \\
Szolnok & 974 & +13 & 1,041 & +80 & 132 \\
Martfü & 926 & +3 & 1,003 & +80 & 115 \\
Tiszaug & 844 & -36 & 932 & +52 & 89 \\
Csongrád & 891 & -80 & 994 & +23 & 59 \\
\hline
\end{tabular}

Source: NAGY, I., KÖTIVIZIG, 2001.

15-20 years. This can only be prevented by governmental interference.

Sedimentation in active floodplains is considerable and will lead higher and higher flood levels in the future, as it can be seen on the example of the Tisza, Danube or Körös rivers. A new flood-control concept is also necessary for the Danube which would employ new approaches to flood-level reduction (e.g. floodway reconstruction, water diversion, storage and others) and the raising of the design height of dykes only where the previous techniques remained unsuccessful. In many places of the floodways of large rivers it is visible that the zones where floods are conveyed unhindered are significantly reduced through groynes, higher summer dykes (levees), forestation or housing development (Figure 5).

Dense vegetation in the floodway and next to the channel promotes the settling out of sediment load. Therefore, if this geomorphic process is neglected, higher flood levels are to be expected in the future. Within a reasonable time there is no real chance for a new flood channel to form and the opportunity for raising dykes and building reservoirs in the low floodplain level is restricted or even excluded by both engineering and financial considerations. In addition to these three options, a fourth one has to be mentioned: the preparation of society for a new-style river regulation, establishment of new channels.

Since the beginning of river regulation efforts 150 years elapsed. Since then the active floodplains have filled up, narrowed and higher and higher floods of increasing frequency and duration are predicted, primarily as a consequence of sedimentation in active

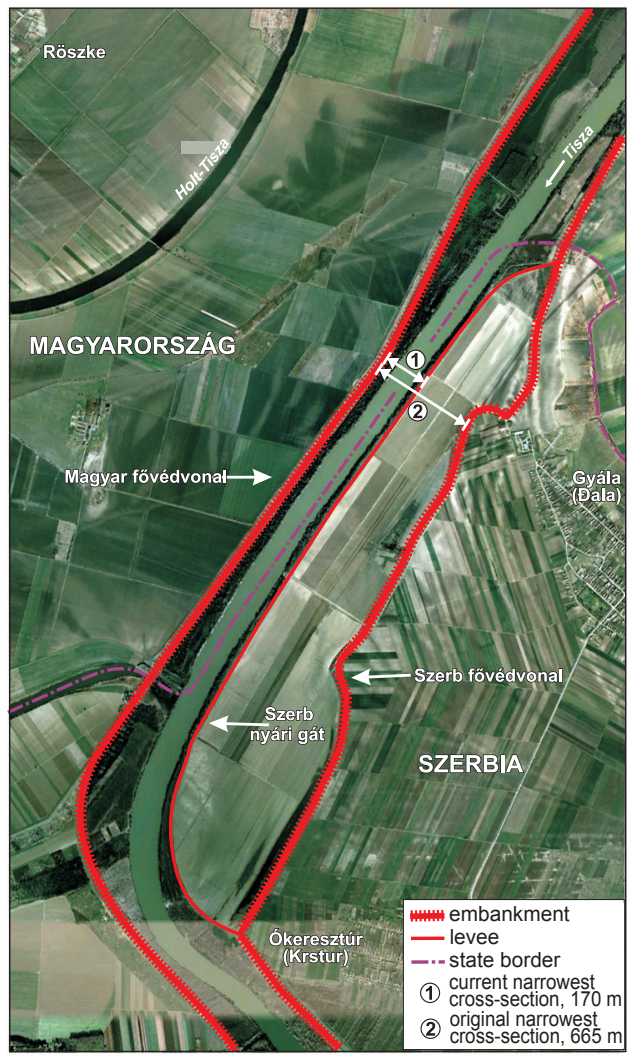

Fig 5. Shrinkage of active floodplain of Tisza in Serbia due to the construction of levees (eds: NAGY, I. and SchweItzer, F. 2011 by using Google Earth images) 
floodplains and developments in the embayments of low floodplain levels, along the Danube at Pilismarót, Pomáz, Békásmegyer, Káposztásmegyer (Budapest) and Adony and along the Tisza in the environs of Szeged and Hódmezővásárhely. The plans and decisions of new river regulation have to be made soon. The Department of Geomorphology, Geographical Research Institute, Hungarian Academy of Sciences, and the author of the present paper have prepared, based on geomorphological and hydrogeographical investigations such plans for flood control along the Danube at Budapest, Paks and Komárom, for the Tisza at Szeged or for Lake Balaton.

Intensive urbanization in the Balaton catchment, the refilling of the karst reservoir in the wake of closing bauxite mines since the 1990s and the re-emergence of karst springs will increase the amount of water stored in Lake Balaton. A turning point in the development of the region was the construction of the southern railway. Its planners designed the track at $107.7 \mathrm{~m}$ elevation, higher than maximum lake water level. In the winter of 1860 raised water level and ice accumulation destroyed the railway track. As a reaction, the Balaton shore was enforced, some sections - particularly on the southern shore - were filled up, reclaimed areas protected by stone revetments were allotted for development. Datings by ${ }^{137} \mathrm{C}$ s show that the lake bottom was affected by sedimentation of almost 20 $\mathrm{cm}$ since the beginning of nuclear experiments (1953) and another almost $10 \mathrm{~cm}$ since the Chernobil event (1986). Therefore, in the future the Siófok Sluice, already existing in Roman times, and the Sió canal is to be supplemented with a new outlet, gravitationally conducting water into the Mura River during floods (Schweitzer, F. 2014).

\section{Conclusions}

The study of flood levels shows that the rise has considerably accelerated and the height of flood waves surpassed the crown of the embankment along more than $200 \mathrm{~km}$ length of the Tisza (NAGY, I. et al. 2001). As a result of the deteriorated conductivity of flood channels, for instance, the growth of flood waves on the Tisza between 1970 and 2013 reached 2-3 cm per year. This can be observed on the Danube, where average increase amounted to $1.40 \mathrm{~cm}$ per year between Vác and Budapest over the same period, on the Körös, where it was $1.60 \mathrm{~cm}$ per year at Békésszentandrás since 1890 and in case of the Ipoly. In practice it means that if the 2000 Tisza flood were repeated today, the flood channel would not be able to convey that flood wave and only the emergency reservoirs could give some hope to avoid disaster. The marked rise of flood levels could be interpreted as warning for the Danube too as $20-25 \mathrm{~cm}$ sedimentation is expected in the active Danube floodplain in the Danube Bend, north of Budapest, in the next 10 years (Figure 6).

The key to flood control in Budapest, a city of 1.8 million, inhabited from Roman times, is river regulation. The main channel of the Danube crosses the city in $31 \mathrm{~km}$ length. Together with the banks of tributaries the length of flood-control dykes amounts to $83.6 \mathrm{~km}$. As attested by written documents available since 1112, flood hazard has ever belonged to city life. The greatest disaster was the ice-jam flood of 1838 (Figure 7).

After the flood plans for not only the Danube section of Pest-Buda, but for all major rivers in Hungary were prepared and submitted to the government. Naturally, lack of financing in times of the revolution and war of independence prevented the implementa-

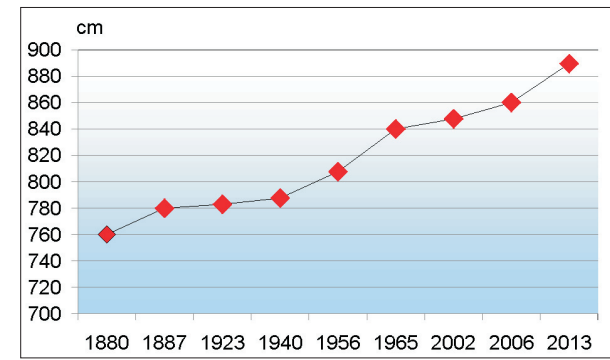

Fig. 6. Rising of peaks of largest ice-free flood levels on the Danube section at Budapest between 1880 and 2013 (completed after DÉGEN, I.) 


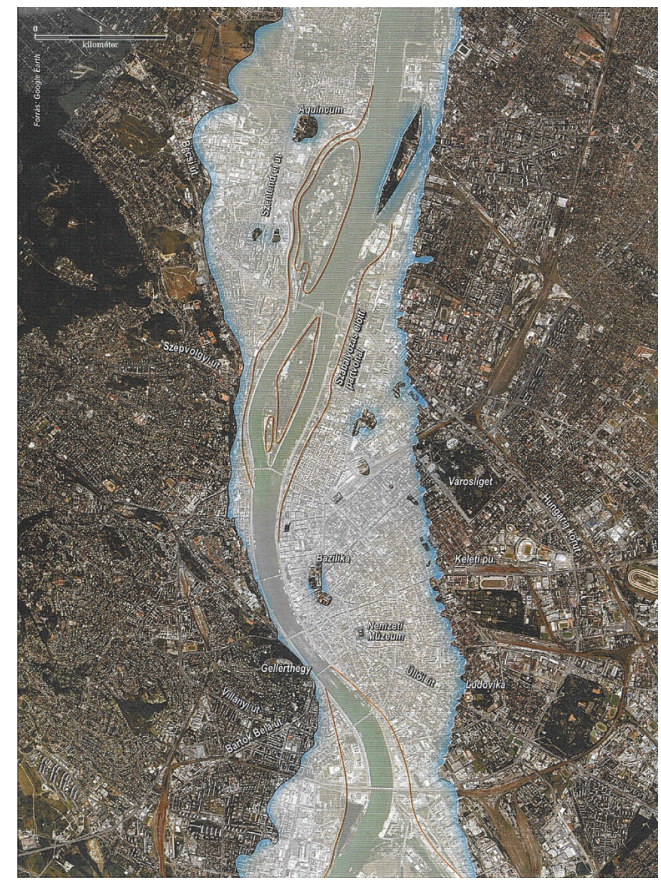

Fig 7. Flood damage map of 1838 superimposed on the current area of Budapest. Google Earth images (ed. by TAKÁcs, K. in 2009 after KáROLYI, Z. 1960)

tion of plans. Instead the filling of low-lying areas, Danube branches between one-time islands, abandoned channels, backswamps, began mostly using industrial waste and household garbage.

Between 1871 and 1875 the Soroksár Danube branch was closed by Gubacs dam and the channel section with numerous bars downstream Pest was narrowed down, resulting in the sedimentation of the Soroksár branch which continues to our days. In the spring of 1876 two flood waves similar to the 1838 level occurred on the Danube again endangering Budapest. This was commonly explained by the closure of the Soroksár Danube and its eliminated water conduction. Over the past 60-70 years ice-free flood levels have remarkably risen in Budapest: 1956: 721 $\mathrm{cm}, 1975: 776 \mathrm{~cm}, 1991: 781 \mathrm{~cm}, 2002: 848 \mathrm{~cm}$, 2006: $860 \mathrm{~cm}$ and 2013: $890 \mathrm{~cm}$.

Modifications of the floodway signify an impending disaster. In order to avert it, author proposes a solution affecting the left- bank zone between Vác and Göd, where topographic conditions are favourable for flood hazard alleviation and urban infrastructure is not an obstacle. Another option is to protect the 800,000 inhabitants of the historical city applying mobile dykes along the main defence line and the tributaries.

To reduce flood hazard, the active floodplains of rivers have to be widened on the Hungarian, Slovakian, Subcarpathian and Vojvodina sections, water storage on the low floodplain level, the creation of new flood channels and setback of flood-control dykes and locally the broadening of active floodplains to the margins of higher levels as natural levees (Figure 4).

The areas suitable for flood and excess water storage have to be utilized for that purpose in the regional plans, excluded from development, land purchase have to be prohibited and land use regulated in the interest of flood-control strategy. Disinterest in flood protection and national security is manifested in public thinking which allowed the alignment of the M6 motorway cutting through the Adony embayment, which could have been capable to store considerable amounts of floodwater and reserve drinking water with gravels of Danube origin in great thickness between Ercsi and Kulcs (NAGY, I. et al. 2010). Instead of momentary solutions politics have to decide for change. If this does not happen, floods would require much suffering and human toll in the country - not to speak of the enormous expenses of reconstruction. The estimated damage associated with the 2006 Danube and Tisza floods surpassed 135 billion HUF. In the case of the Tisza flood in 2000 eight million sand bags were built-in in the dykes and flood defence involved additional high costs. The 2013 Danube flood also caused huge damage.

In Hungary the tasks to be undertaken now are similar to those in the 1830s and 1940s. Long-term strategic decisions have to be made in order the ensure security for the population living in river valleys and floodplains and for agriculture and industrial structures. 


\section{REFERENCES}

Braun, M., Dezsó, Z. and Hadady, Gy. 2001. A Tisza balpart, Szolnok övzátony fejlődésének rekonstrukciójáról (On the reconstruction of the natural levee at Szolnok, left bank of the Tisza River). Debrecen, Manuscript.

IHrIG, D. 1952. A magyar vízszabályozás története (History of river regulation in Hungary), Budapest, VITUKI.

KÁROLYI, Z. 1960. A hordalékmozgás jellegzetességei folyók medrében (Characteristics of sediment movements in river channel). Hungarian Geographical Bulletin / Földrajzi Értesítō 9. (1): 90-96.

Nagy, I., Ligetvári, F. and Schweitzer, F. 2010. Tisza river valley: future prospects. Hungarian Geographical Bulletin 59. (4): 361-370.

Nagy, I., Schweitzer, F. and Alföldi, L. 2001. A hullámtéri hordalék-lerakódás (övzátony) (Sedimentation on active floodplain, natural levee formation). Vízügyi Közlemények 83. (4): 539-564.

PÁlfai, I. 2004. Belvizek és aszályok Magyarországon (Excess water and drought periods in Hungary). Budapest, KVM.

Schweitzer, F. 2000. A magyarországi folyószabályozások geomorfológiai vonatkozásai (Geomorphological aspects of river regulation in Hungary). Hungarian Geographical Bulletin / Földrajzi Értesitó 50. (1-4): 63-72.

Schweitzer, F. 2009. Strategy or disaster: flood prevention related to issues and actions in the Tisza River Basin. Hungarian Geographical Bulletin 58. (1): 3-17.

Schweitzer, F. and NAgY, I. 2011. Döntési kényszer a hazai árvízvédelemben (Force to make decisions in the flood protection of Hungary). In Katasztrófák tanulságai. Ed.: SchweITzer, F. Budapest, MTA CSFK Földrajztudományi Intézet, 13-68.
TAKÁcs, K. 2009. Ha a jég az úr: jeges árvizek a Dunán. (When the ice is the lord: icy floods on the Danube). A Földgömb 2. 60-69.

VáGÁs, I. 1982. A Tisza árvizei (Floods of the Tisza river). Budapest, VÍZDOK.

VÁGÁs, I. 1984. A folyók vízhozamának és vízállásának kapcsolatai (Water discharge and water stage on rivers). Hidrológiai Közlöny 64. (3): 142-147.

\section{ADDITIONAL SOURCES}

Lóczy, D., Fábián, Sz.Á. and Schweitzer, F. 2008. River action and landslides in Hungary. In Issues in geomorphology and environment. Eds.: BAsU, S.R. and DE, S.K. Kolkata, ACB, 1-15.

Mosonyi, E. 1999. A mértékadó árvíz. (The design flood stage). Vízügyi Közlemények 81. (2): 201-220.

Schweitzer, F., BAlogh. J. and Kis, É. 2008. Hullámterek vizsgálata a Dél-Alföldön. (Studies on flood plains in southern areas of the Hungarian Lowland). Hungarian Geographical Bulletin / Földrajzi Értesitö 57. (1-2): 111-123.

SomLyódy, L. (ed.) 2000. A hazai vízgazdálkodás stratégiai kérdései. (Strategical questions in water management in Hungary). Budapest, MTA Vízgazdálkodási Tudományos Kutatócsoport.

VARGA, M. and VÁRAdI, J. 2010. Vízvisszatartás - tározás - vidékfejlesztés: javaslatok a vízgazdálkodás hosszú távú fejlődési irányaihoz. (Water-retention - storage - rural development: recommendations to long-term development directions of water management). Budapest, MTA Történettudományi Intézet. 


\title{
Ukraine in Maps
}

\author{
Edited by: Kocsis, K., Rudenko, L. and Schweitzer, F.
}

\author{
Institute of Geography National Academy of Sciences of Ukraine \\ Geographical Research Institute Hungarian Academy of Sciences. \\ Kyiv-Budapest, 2008, 148 p.
}

Since the disintegration of the USSR, the Western world has shown an ever-growing interest in Ukraine, its people and its economy. As the second-largest country in Europe, Ukraine has a strategic geographical position at the crossroads between Europe and Asia. It is a key country for the transit of energy resources from Russia and Central Asia to the European Union, which is one reason why Ukraine has become a priority partner in the neighbourhood policy of the EU. Ukraine has pursued a path towards the democratic consolidation of statehood, which encompasses vigorous economic changes, the development of institutions and integration into European and global political and economic structures. In a complex and controversial world, Ukraine is building collaboration with other countries upon the principles of mutual understanding and trust, and is establishing initiatives aimed at the creation of a system that bestows international security.

This recognition has prompted the Institute of Geography of the National Academy of Sciences of Ukraine (Kyiv) and the Geographical Research Institute of the Hungarian Academy of Sciences (Budapest) to initiate cooperation, and the volume entitled "Ukraine in Maps" is the outcome of their joint effort. The intention of this publication is to make available the results of research conducted by Ukrainian and Hungarian geographers, to the English-speaking

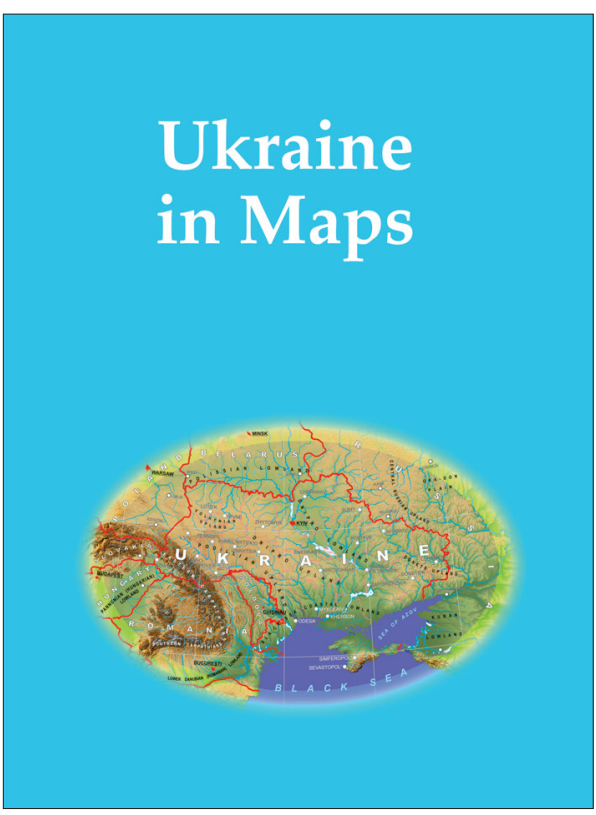
public. This atlas follows in the footsteps of previous publications from the Geographical Research Institute of the Hungarian Academy of Sciences. Similar to the work entitled South Eastern Europe in Maps (2005, 2007), it includes 64 maps, dozens of figures and tables accompanied by an explanatory text, written in a popular, scientific manner. The book is an attempt to outline the geographical setting and geopolitical context of Ukraine, as well as its history, natural environment, population, settlements and economy. The authors greatly hope that this joint venture will bring Ukraine closer to the reader and make this neighbouring country to the European Union more familiar, and consequently, more appealing.

Price: EUR 35.00

Order: Geographical Institute RCAES HAS Library

H-1112 Budapest, Budaörsi út 45.

E-mail: magyar.arpad@csfk.mta.hu 